\title{
Myocardial Ischemia Reperfusion Injury: Apoptotic, Inflammatory and Oxidative Stress Role of Galectin-3
}

\author{
Suhail Al-Salam ${ }^{\mathrm{a}}$ Satwat Hashmi \\ aDepartment of Pathology, College of medicine and health Sciences, United Arab Emirates University, \\ $\mathrm{UAE}$, 'bepartment of Biological and Biomedical Sciences, Agha Khan University, Pakistan
}

\section{Key Words}

Heart $•$ Myocardial ischemia reperfusion • Galectin 3

\begin{abstract}
Background/Aims: Myocardial reperfusion has the potential to salvage the ischemic myocardium after a period of coronary occlusion. Reperfusion, however, can cause a wide spectrum of deleterious effects. Galectin-3 (GAL-3), a beta galactoside binding lectin, is closely associated with myocardial infarction (MI), myocardial fibrosis and heart failure. In our study, we investigated its role in ischemia-reperfusion injuries (IR) as this phenomenon is extremely relevant to the early intervention after acute MI. Methods: C57B6/J wild type (WT) mice and GAL-3 knockout (KO) mice were used for murine model of IR injury in the heart where a period of 30 minutes ischemia was followed by 24 hours of reperfusion. Heart samples were processed for immunohistochemical and immunofluorescent labeling, morphometric analysis, western blot and enzyme-linked immunosorbent assay to identify the apoptotic, inflammatory and oxidative stress role of GAL-3. Results: Our results show that there was a significant increase in GAL-3 levels in the heart which shows GAL-3 is playing a role in the ischemia reperfusion injury. Troponin I was also significantly higher in GAL-3-KO group than wild type. Our study shows that GAL-3 is associated with an increase in the antioxidant activity in the IR injured myocardium. Antioxidant enzymes superoxide dismutase, glutathione and catalase were found to be significantly raised in the GAL-3 wild type IR as compared to the GAL-3 KO IR group. A significant increase in apoptotic activity is seen in GAL-3 KO IR group as compared with GAL-3 wild IR group. Conclusion: Our study shows that GAL-3 can affect the redox pathways, controlling cell survival and death, and plays a protective role on the myocardium following IR injury.

Dr. Suhail Al-Salam, MBChB, FRCPath Professor, Consultant Pathologist
Department of Pathology, College of medicine and health Sciences, United Arab Emirates University,
ALAIN PO Box 17666 (UAE)

Tel. +97137137464, Fax +97137671966, E-Mail suhaila@uaeu.ac.ae 


\section{Cellular Physiology Cell Physiol Biochem 2018;50:1123-1139 and Biochemistry \begin{tabular}{l|l} 
DOI: 10.1159/000494539 & $\begin{array}{l}\text { C } 2018 \text { The Author(s). Published by S. Karger AG, Basel } \\
\text { www.karger.com/cpb }\end{array}$
\end{tabular}}

Al-Salam et al.: Role of Galectin-3 in Myocardial Ischemia Reperfusion Injury

\section{Introduction}

Early and successful myocardial reperfusion after an acute myocardial infarction (MI) is the most effective strategy for salvaging the myocardium and improving clinical outcomes. This process of restoring blood flow to the ischemic myocardium can, however, induce myocardial reperfusion injury and paradoxically reduce the beneficial effects of myocardial reperfusion. This injury results in the death of cardiac myocytes that were viable immediately before myocardial reperfusion [1], hence, despite prompt myocardial reperfusion, the rate of death after an acute MI approaches $9 \%$, and the incidence of cardiac failure is almost $10 \%$ at 1 year $[2,3]$.

The concept of ischemia reperfusion (IR) injury was first introduced when scientists noticed that a large fraction of cellular enzymes were released not during hypoxia, but on sudden re-oxygenation [4]. This re-oxygenation of ischemic myocardium generates a degree of myocardial injury that exceeds injury induced by ischemia alone [4]. Timely reperfusion after MI can reduce the size of infarction up-to half, which means that reperfusion itself accounts for up-to $50 \%$ of final infarct size [5]. Reperfusion is also shown to affect a larger portion of the left ventricle than infarction alone, so IR injury may act as an independent determinant of cardiac remodeling [6].

IR injury is a combination of events that begins with oxidative stress, inflammation, intracellular $\mathrm{Ca}+$ overload and subsequent progression into irreversible cell death by apoptosis and necrosis $[7,8]$. Understanding the contribution of these processes to IR injury is essential to look for therapeutic measures that can help reduce the myocardial infarct size and cardiac remodeling; both crucial determinants of prognosis.

Galectin-3 (GAL-3) is unique chimera-like galectin belonging to the family of lectins that specifically bind to $\mathrm{N}$-acetyl-lactosamine-containing glycoproteins [9]. GAL-3 is expressed in a variety of cells, e.g., endothelial and epithelial cells, activated macrophages, microglial cells, basophils, mast cells, neutrophils, neurons and cardiomyocytes [10-16]. So far we know that GAL-3 is closely associated with myocardial infarction in the early post MI period and later with myocardial fibrosis and heart failure $[15,17]$. Our aim is to further investigate if GAL-3 has any role in IR injury of the myocardium.

The generation of reactive oxygen species (ROS) acts as central mediators of IR injury. These species can initiate spontaneous, and self-propagating radical reactions with biomolecules that impair myocardial function by activating intracellular proteolytic enzymes and induce cell death by initiating mitochondrial permeability transition $[18,19]$. Most cells including cardiomyocytes contain enzymatic antioxidant defense mechanisms that quickly convert ROS to water. These antioxidant systems include superoxide dismutase, catalase, and the glutathione (GSH) redox system [20]. In addition to looking at the antioxidant enzyme activity in relation to GAL-3, we will look into the role of NRF2 (Nuclear factor-erythroid 2 (NF-E2)-related factor 2) which is a redox-sensitive transcription factor that up-regulates cytoprotective and antioxidant genes expression to protect against IR injury. During resting state, NRF2 is located in the cytoplasm sequestered with a cytoskeletal associated protein Keap 1 (Kelch-like ECH-associated protein 1). Keap 1 negatively regulates NRF2 by promoting its ubiquitination and proteosomal degradation. When released from Keap 1, NRF2 translocate to the nucleus and binds as a heterodimer to the antioxidant response elements (ARE) located in the promoter region of genes encoding many antioxidant enzymes [21-24]. NRF2 thus controls GSH production and regeneration and its utilization among other antioxidant pathways [25]. Also in the myocardium, NRF2 is a critical element of redox homeostasis [26, 27]. Recently it has been demonstrated that in addition to protection against oxidative stresses NRF2 responds to pro-inflammatory stimuli and protects against inflammatory injuries and fibrosis [28-30].

We hypothesize that GAL-3 has a protective role on the myocardium during IR injury. We have used a murine model of myocardial ischemia-reperfusion injury with a period of 30 min ischemia followed by 24 hours of reperfusion to investigate the protective role of GAL-3 in IR injury through measuring myocardial inflammatory markers (IL-6, CRP, MPO, elastase), 
cell death markers (Troponin I, cleaved caspase-3, cytochrome c, annexin V), cell survival marker (Bcl2) and anti-oxidant markers (GSH, catalase, SOD, NRF2, glutathione reductase, glutathione peroxidase).

\section{Materials and Methods}

\section{Murine model of myocardial ischemia reperfusion injury}

C57B6/J wild type (WT) ( $n=16$ ) and GAL-3 knockout (KO) (The Jackson Laboratory, 006338, galactin3-, B6 Cg-Lgals3 <tm 1 Poi>/J HOM Homozygous genotype) ( $n=16)$ mice were used in this experiment. All animals were male, aged 12-16 weeks and weighed 20-25 grams. Sham operated animals $(n=16)$ for each group were also studied. In each group 8 hearts were collected for protein analysis while the other 8 hearts were collected for histological analysis.

All experimental animal procedures were approved by the Animals Ethics Committee of the College of Medicine and Health Sciences, UAE University.

Wild type and GAL-3 KO mice were anesthetized by an intraperitoneal injection of a combination of Ketamine $(100 \mathrm{mg} / \mathrm{kg})$ and Xylazine $(10 \mathrm{mg} / \mathrm{kg})$. The mice were then intubated and connected to a mouse ventilator (Harvard apparatus Minivent Hugo Sachs Electronik) which supplied room air supplemented with $100 \%$ oxygen (tidal volume $0.2 \mathrm{ml} / \mathrm{min}$., rate 120 strokes/min). Body temperature was continuously monitored and maintained within $36-37^{\circ} \mathrm{C}$. The lead II ECG (ADInstrument multi-channel recorder interfaced with a computer running Power lab 4/30 data acquisition software) was recorded from needle electrodes inserted subcutaneously. Myocardial infarction was induced in the mice by permanently occluding the left anterior descending coronary artery (LAD) as described earlier [31-33].

Briefly, the chest was opened with a lateral incision at the $4^{\text {th }}$ intercostal space on the left side of the sternum. Next the chest wall was retracted for better visualization of the heart. With minimal manipulation, the pericardial sac removed and the left anterior descending artery (LAD) visualized with a stereomicroscope (Zeiss STEMI SV8). An 8-0 silk suture was passed under the LAD, a small $1 \mathrm{~mm}$ polyethylene tubing (PE) was placed on top of the LAD and the suture was ligated on the top of the PE tubing without damaging the artery. Ischemia was confirmed by the pale discoloration of the left ventricle. An accompanying ECG also showed corresponding ST- elevation. After 30 minutes of ischemia the ligature is removed by cutting the knot on top of this PE tube. Reperfusion was confirmed visually and by ECG changes.

The chest wall was closed by approximating the third and fourth ribs with one or two interrupted sutures. The muscles returned back to their original position and the skin closed with 4-0 prolene suture. The animal was gently disconnected from the ventilator and spontaneous breathing was seen immediately. Postoperative analgesic (Butorphanol $2 \mathrm{mg} / \mathrm{kg}$, s/c, 6 hourly) was given at the end of the procedure. Sham operated mice underwent exactly the same procedure described above, except that the suture passed under the LAD is left open and untied. According to the experimental protocol, mice were sacrificed 24 hours after induction of myocardial ischemia reperfusion. The hearts were washed in ice cold PBS, right ventricle and both atria dissected away and left ventricle immediately frozen in liquid nitrogen and later stored in $-80^{\circ} \mathrm{C}$ freezer. Blood was also collected in EDTA vacutainers and centrifuged at 3000 RPM for 15 minutes. The plasma was collected, alliquoted and stored at $-80^{\circ} \mathrm{C}$ until further analysis. Heart samples from the same time point following LAD ligation were fixed in $10 \%$ buffered formal-saline for 24 hours.

\section{Protein extraction from samples}

Total protein was extracted from heart samples by homogenizing with lysis buffer and collecting the supernatant after centrifugation. The Left ventricular (LV) heart samples were thawed, weighed and put in cold lysis buffer containing $50 \mathrm{mM}$ Tris, $300 \mathrm{mM} \mathrm{NaCl}, 1 \mathrm{mM} \mathrm{MgCl} 2,3 \mathrm{mM}$ EDTA, $20 \mathrm{mM} \beta$-glycerophosphate, $25 \mathrm{mM} \mathrm{NaF}, 1 \%$ Triton X-100, 10\%w/v Glycerol and protease inhibitor tablet (Roche Complete protease inhibitor cocktail tablets). The hearts were homogenized on ice by a homogenizer (IKA T25 Ultra Turrax). The samples were then centrifuged at $14000 \mathrm{RPM}$ for 15 minutes at $4{ }^{\circ} \mathrm{C}$, supernatant collected, alliquoted and stored at $-80^{\circ} \mathrm{C}$ until further analysis. Total protein concentration was determined by BCA protein assay method (Thermo Scientific Pierce BCA Protein Assay Kit). 


\section{Cellular Physiology Cell Physiol Biochem 2018;50:1123-1139 and Biochemistry \begin{tabular}{l|l} 
DOI: 10.1159/000494539 & $\begin{array}{l}\text { O } 2018 \text { The Author(s). Published by S. Karger AG, Basel } \\
\text { wwww.karger.com/cpb }\end{array}$
\end{tabular}}

al-Salam et al.: Role of Galectin-3 in Myocardial Ischemia Reperfusion Injury

\section{Immunohistochemistry}

Hearts were excised, washed with ice-cold (PBS), blotted with filter paper and weighed. Each heart was sectioned into coronal slices of $2 \mathrm{~mm}$ thickness then cassetted and fixed directly in $10 \%$ neutral formalin for 24 hours, which was followed by dehydration in increasing concentrations of ethanol, clearing with xylene and embedding with paraffin. Five-micrometer sections were prepared and mounted on aminopropyltriethoxysilane (APES) coated slides. After dewaxing with xylene and rehydrating with graded alcohol, slides were placed in a $0.01 \mathrm{M}$ citrate buffer solution $(\mathrm{pH}=6.0)$ and pre-treatment procedures to unmask the antigens was performed in a water bath at $95^{\circ} \mathrm{C}$ for 30 minutes. Then, sections were treated with peroxidase block for 60 minutes followed by protein block for 60 minutes. Sections were incubated overnight with anti- GAL-3 antibody (rabbit anti-mouse polyclonal antibody 1:2500, Davids Biotechnologie GmbH, Germany) and anti-Catalase antibody (Rabbit Polyclonal, 1:400, Sigma, USA) at $4^{\circ} \mathrm{C}$. While other sections were incubated with anti- cleaved caspase-3 antibody (Rabbit Polyclonal, 1:300, Cell signaling technology, USA), anti-cytochrome $C$ antibody (Rabbit Polyclonal, 1:300, Cell signaling technology, USA), anti-nuclear factor erythroid 2-related factor 2(NRF-2) antibody (Rabbit Polyclonal, 1:100, Abcam, USA), anti-glutathione peroxidase antibody (Rabbit Polyclonal, 1:300, Abcam, USA), Anti- Superoxide dismutase (SOD) antibody (Rabbit Polyclonal, 1:300, Abcam, USA), anti-glutathione reductase antibody (Rabbit Polyclonal, 1:300, Abcam, USA), for one hour at room temperature. After conjugation with primary antibodies, sections were incubated with secondary antibody (EnVisionTM Detection System, DAKO, Agilent, USA) for 20 minutes at room temperature followed by addition of DAB chromogen (EnVisionTM Detection System, DAKO, Agilent, USA) and counter staining done with haematoxylin. Appropriate positive controls were used. For negative control, the primary antibody was not added to sections. Positive and negative controls were used in every batch of slides that were stained (not shown in figures).

\section{Immunofluorescent labeling}

Five-um sections were deparaffinised with xylene and rehydrated with graded alcohol. Sections were placed in EnVisionTM FLEX Target Retrieval Solution with a high PH (PH 9) (DAKO Agilent, USA) in a water bath at $95^{\circ} \mathrm{C}$ for 30 minutes hour. Sections were washed with distilled water for 5 minutes followed by PBS for 5 minutes. Later they were incubated with anti-catalase (Rabbit Polyclonal, 1:100, Sigma, USA) antibody, anti-annexin-V antibody (Rabbit Polyclonal, 1:100, Abcam, USA), anti-myeloperoxidase (MPO) antibody (Rabbit Polyclonal, 1:100, Abcam, USA), overnight at room temperature. Sections were subsequently incubated with donkey anti-rabbit Alexa Fluor 488, (Invitrogen, USA, 1:100) antibody. Finally, sections were mounted in water-soluble mounting media and viewed with Olympus Fluorescent microscope. Appropriate positive control sections were used. For negative control, the primary antibody was not added to sections and the whole procedure carried out in the same manner as mentioned above.

\section{Morphometric analysis}

Morphometric analysis of NRF2, SOD, glutathione reductase, glutathione peroxidase, catalase, cytochrome c, cleaved caspase- 3 and annexin V expression in left ventricular cells was done at $24 \mathrm{~h}$ following ischemia reperfusion using ImageJ software (http://rsbweb.nih.gov/ij/). NRF2, SOD, glutathione reductase, glutathione peroxidase, catalase, cytochrome c, cleaved caspase- 3 and annexin v labeling were determined by counting the number of positive cells in randomly-selected high power fields (HPF) in the left ventricle. The mean numbers of positive cells will be converted from per HPF to per $\mathrm{mm}^{2}$ (Each $\mathrm{mm}^{2}$ $=4 \mathrm{HPF}$ ). For NRF2 labeling, cells were considered positive when there was a nuclear staining pattern. For SOD, glutathione reductase, glutathione peroxidase, catalase, cytochrome c, cleaved caspase-3 labeling, cells were considered positive when there was a cytoplasmic staining pattern. For annexin $\mathrm{V}$ labeling, cells were considered positive when there was a membranous/cytoplasmic staining patterns.

\section{Western blotting}

Total protein extracts $(50 \mathrm{ug}$ ) from each sample were resolved by SDSPAGE on $12.5 \%$ and $15 \%$ polyacrylamide gels depending on the molecular weight of the protein. The protein on gels was electrotransferred onto a Polyvinylidene difluoride (PVDF) membrane using Bio-Rad tank transfer system. The membranes were blocked in 5\% non-fat dry milk solution in TBST for one hour at room temperature. The membranes were subsequently incubated overnight with primary antibodies anti- cleaved caspase-3 (Rabbit Polyclonal, 1:1000, Cell signaling technology, USA), anti-cytochrome C (Rabbit Polyclonal, 1:1000, 


\section{Cellular Physiology Cell Physiol Biochem 2018;50:1123-1139 \begin{tabular}{l|l|l} 
DOl: 10.1159/000494539 & O 2018 The Author(s). Published by S. Karger AG, Basel \\
wwww.karger.com/cpb
\end{tabular}}

Al-Salam et al.: Role of Galectin-3 in Myocardial Ischemia Reperfusion Injury

Cell signaling technology, USA), anti BAX (Rabbit Polyclonal, 1:1000, Abcam, USA), anti-BCL2 (Rabbit Polyclonal, 1:1000, Abcam, USA), diluted in blocking buffer with gentle shaking at $4{ }^{\circ} \mathrm{C}$ overnight. Membranes were also incubated overnight $4^{\circ} \mathrm{C}$ for Beta-actin antibody Rabbit Polyclonal, 1:1000, Cell signaling technology, USA), diluted in TBST to control for equal loading. Blots were then incubated with horseradish peroxidase-conjugated secondary antibodies (rabbit anti-mouse Thermo-Pierce) and developed using ECL plus substrate (Thermo Pierce). Protein bands were visualized by a laser scanner (Typhoon FLA 9500, GE Healthcare Bio-Sciences AB, Sweden). Densitometric analysis of the protein bands was analyzed using image J software (https://imagej.nih.gov/ij/), NIH, USA. The blot intensities were normalized with that of $\beta$-actin as loading control.

\section{Enzyme linked immunosorbent assay}

Left ventricular myocardial concentration of GAL-3, c-reactive protein (CRP), neutrophil elastase, myeloperoxidase (MP0), interleukin-6 (IL-6), and cleaved caspase-3 were determined using DuoSet enzyme linked immunosorbent assay (ELISA) development kits [mouse galectin-3 (DY1197), mouse CRP (DY1829), mouse neutrophil elastase (DY4517), mouse MPO (DY 3667), mouse IL-6 (DY 406) and mouse cleaved caspase-3 (DYC 835), R\&D Systems, Minneapolis, MN, USA] for sandwich ELISA, using standard procedure according to the manufacturer's instructions. The levels were normalized to total protein concentrations. Briefly, 96-well plates Nunc-Immuno Plate MaxiSorp Surface (NUNC Brand Products, A/S, Roskilde, Denmark), were coated with antibody specific our proteins of interest. Biotinylated detection antibody and streptavidin conjugated horseradish peroxidase were used for detection of captured antigens. The plates between steps were aspirated and washed 3 times using ELISA plate washer (BioTek ELx50). Captured proteins were visualized using tetramethylbenzidine (TMB)/hydrogen peroxide. Absorbance readings were made at $450 \mathrm{~nm}$, using a 96-well plate spectrophotometer (BioTek ELx800). Concentrations in the samples were determined by interpolation from a standard curve. Standards and samples were assayed in duplicate.

\section{Glutathione and Catalase activity assay}

Total glutathione level in the heart protein extract was measured by a glutathione (GSH) Assay kit (CS0260 Sigma-Aldrich). Glutathione standard solutions were used to generate a standard curve and GSH levels calculated using Megallan6 software. Catalase activity was measured using Cayman Catalase assay kit (707002, Cayman USA).

\section{Troponin-I Assay}

Mouse cardiac troponin I levels in plasma were measured by using a high sensitivity mouse cardiac Troponin-I Elisa kit (2010-1-HSP, Life Diagnostics, Inc.) according to the manufacturer's instructions.

\section{Statistical analysis}

All statistical analyses were done using GraphPad Prism Software version 5. Comparisons between the various groups were achieved by one-way analysis of variance (ANOVA), followed by Newman-Keuls multiple range tests. Data are presented in mean \pm standard error (S.E). P values $<0.05$ are considered significant.

\section{Results}

GAL-3 is increased after Ischemia-reperfusion injury in the heart

GAL-3 levels were significantly higher in the LV of GAL-3 wild type mice at $30 \mathrm{~min}$ ischemia and 24-hour post reperfusion time point as compared to sham operated mice $(7862 \pm 768.8$ vs $4785 \pm 273.5 \mathrm{pg} / \mathrm{mg}, P<0.001)$ as measured by ELISA (Fig. 1A). Our immunohistochemistry results also show significantly increased expression of GAL-3 in the heart section of IR group (Fig. 1B, D) as compared to sham-operated animals (Fig. 1C, E). 
Fig. 1. A. The graph represents left
ventricular GAL-3
concentrations in the
wild type C57BL6
IR group and GAL-
3 KO IR group with
their corresponding
shams. Data are
shown as means
\pm SEM. Statistical
significance is
expressed P<0.05. $\mathrm{B} \& \mathrm{C} \quad$ represents

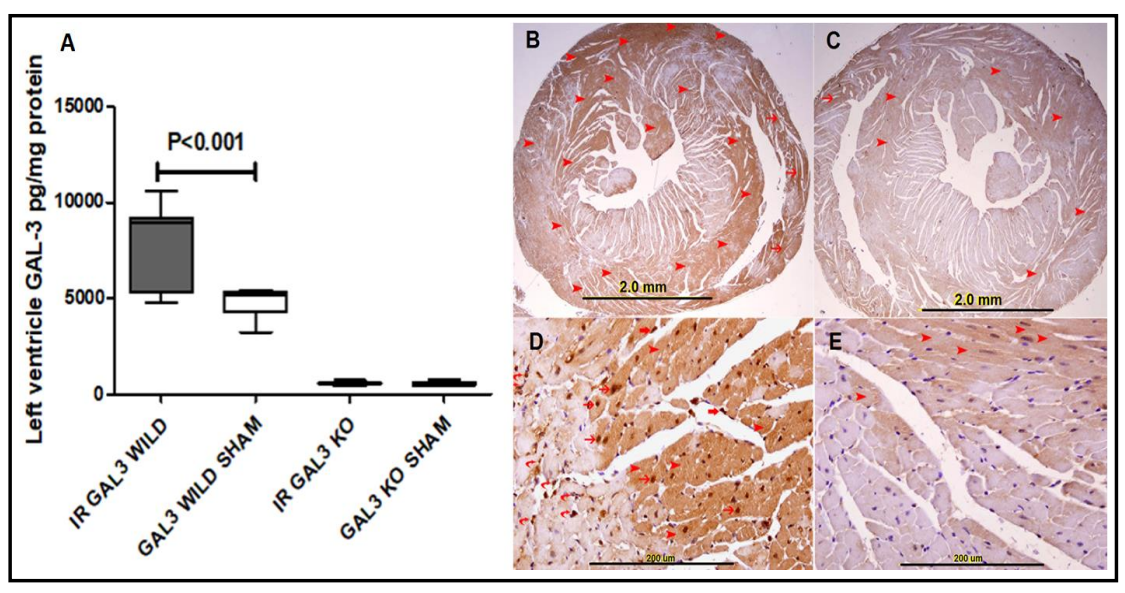
low power view of

heart sections showing GAL-3 expression in IR group (B) as compared to Sham operated control group (C). Expression is seen as more intense staining in the LV area supplied by LAD (arrow heads) as well as right ventricular wall (thin arrow) (B). D\&E show high power view of IR (D) and sham heart sections (E) expressing GAL-3 in the cytoplasm of cardiomyocytes (arrow head) and nuclei (thin arrow), endothelial cells (thick arrow) and neutrophil polymorphs (curved arrow) (D). The intensity and number of positive staining in IR group is higher than the Sham. Streptavidin- biotin immunoperoxidase method.

Fig. 2. A. The graph represents left ventricular IL6 concentrations in the wild type C57BL6 IR group and GAL-3 KO IR group with their corresponding shams. B. The graph represents left ventricular CRP concentrations in the wild type C57BL6 IR group and GAL-3 KO IR group with their corresponding shams. C. The graph represents left ventricular MPO concentrations in the wild type C57BL6 IR group and GAL-3 KO IR group with their corresponding shams. D. The graph represents left ventricular elastase concentrations in the wild type C57BL6 IR group and GAL-3 KO IR group with their

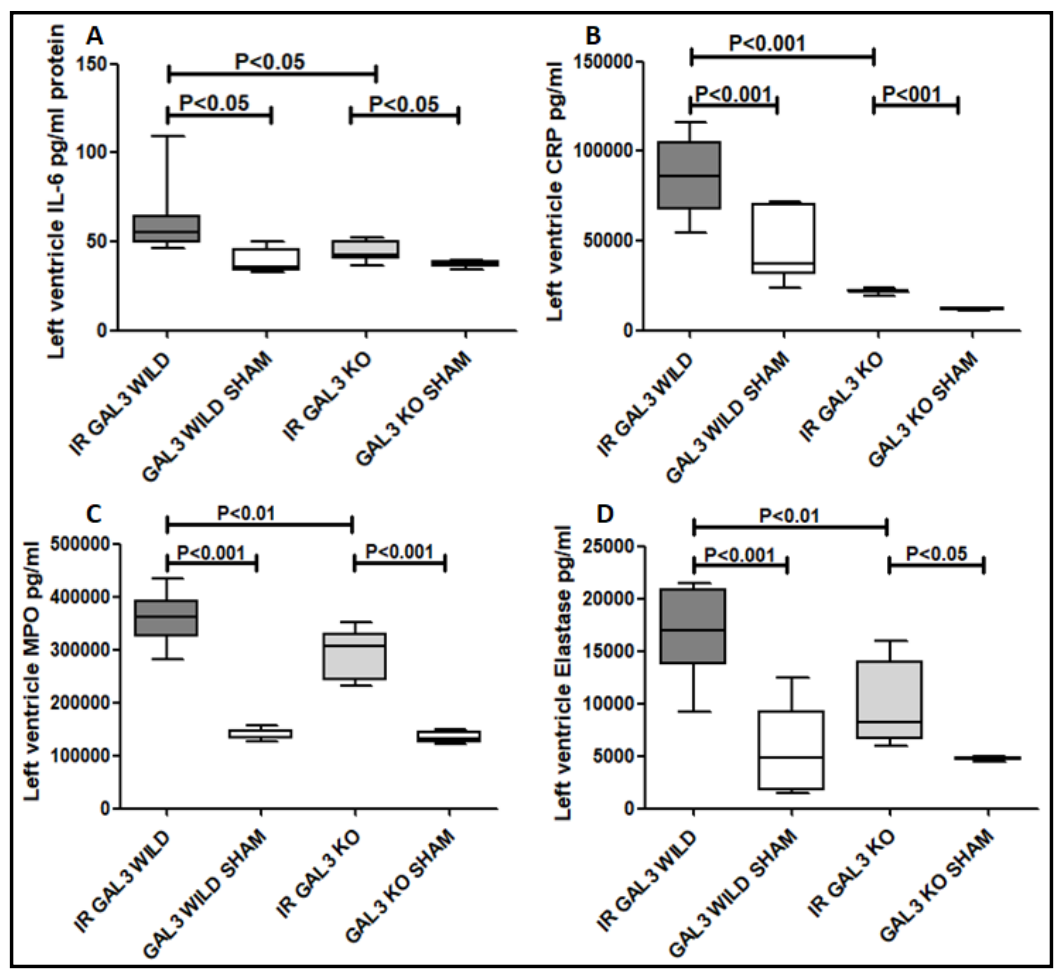
corresponding shams. Data are shown as means \pm SEM. Statistical significance is expressed $\mathrm{p}<0.05$.

GAL-3 is associated with increased inflammatory response following Ischemia-reperfusion injury in the heart

IL-6 levels in the LV of the IR GAL-3 wild group were significantly raised as compared to the IR GAL-3-KO group (61.22 \pm 7.144 vs $44.45 \pm 2.034 \mathrm{pg} / \mathrm{ml}, P<0.05)$ (Fig. 2A). CRP levels in the LV of the IR GAL-3 wild group were significantly raised as compared to the IR GAL3 -KO group ( $86010 \pm 7918$ vs $21470 \pm 545.3 .6 \mathrm{pg} / \mathrm{ml}, P<0.001$ ) (Fig. $2 \mathrm{~B}$ ). Neutrophil MPO 


\section{\begin{tabular}{ll} 
Cellular Physiology & Cell Physiol Biochem 2018;50:1123-1139 \\
\hline DOl: 10.1159/000494539 & | 2018 The Author(s). Published by S. Karger AG, Basel
\end{tabular}

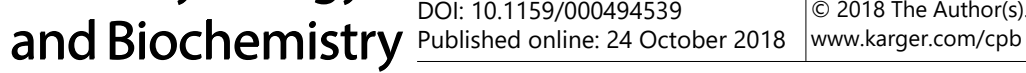

levels in the LV of the IR GAL-3 wild group were significantly raised as compared to IR GAL-3KO group ( $358700 \pm 20320$ vs $293900 \pm 19070 \mathrm{pg} / \mathrm{ml}, P<0.01$ ) (Fig. 2C). Neutrophil elastase levels in the LV of the IR GAL-3 wild group were significantly raised as compared to the IR GAL-3-KO group (16740 \pm 1802 vs $9735 \pm 1643$ pg/ml, $P<0.01)$ (Fig. 2D). Immunofluorescent staining of the heart section with MPO showed a comparatively higher number of neutrophil polymorphs in the IR GAL-3 wild group than IR GAL-3-KO group (Fig. 3).

\section{GAL-3 has an anti-oxidant effect in IR injury}

To assess the effect of GAL-3 on the oxidative stress we measured the status of the antioxidant enzymes total glutathione and catalase in the LV tissue protein extract in the GAL-3 wild type IR group and GAL-3 KO IR group. Total glutathione levels were significantly raised in the GAL-3 wild type IR group (Fig. 4A) compared to the GAL-3 KO IR group $(5.083 \pm 0.6114$ vs $2.707 \pm 0.296 \mathrm{nmol} / \mathrm{mg}$ protein, $P<0.001)$. Total catalase levels were significantly raised in the GAL-3 wild type IR group (Fig. 4B) compared to the GAL3 KO IR group $(183.3 \pm 4.032 \mathrm{vs} 19.90 \pm 1.131 \mathrm{nmol} / \mathrm{min} / \mathrm{ml}, P<0.0001)$. Morphometric analysis of immunohistochemically stained sections of the LV show a significantly higher number of cells showing nuclear expression of NRF2 in GAL-3 wild IR group than in GAL3 KO group ( $90.63 \pm 9.517$ vs $59.38 \pm 8.898, P<0.05$ ) (Fig. 5 A-C). Morphometric analysis of immunohistochemically stained sections of the LV show a significantly higher number of cells showing cytoplasmic expression of SOD (61.63 \pm 3.973 vs $50.13 \pm 2.936, P<0.05$, Fig. 5D-F), and Glutathione reductase ( $43.00 \pm 2.872$ vs $32.50 \pm 3.391, P<0.01$, Fig. $5 \mathrm{G}-\mathrm{I})$

Fig. 3. A\&B. Representative sections of the left ventricle of IR group showing neutrophil polymorphs expressing MPO and infiltrating the myocardium (thin arrow). C\&D. Representative sections of the left ventricle of IR-KO group showing a comparatively lower number of neutrophil polymorphs with similar expression of MPO, when compared to the IR group, and infiltrating the myocardium (thin arrow), (Alexa Fluor 488).

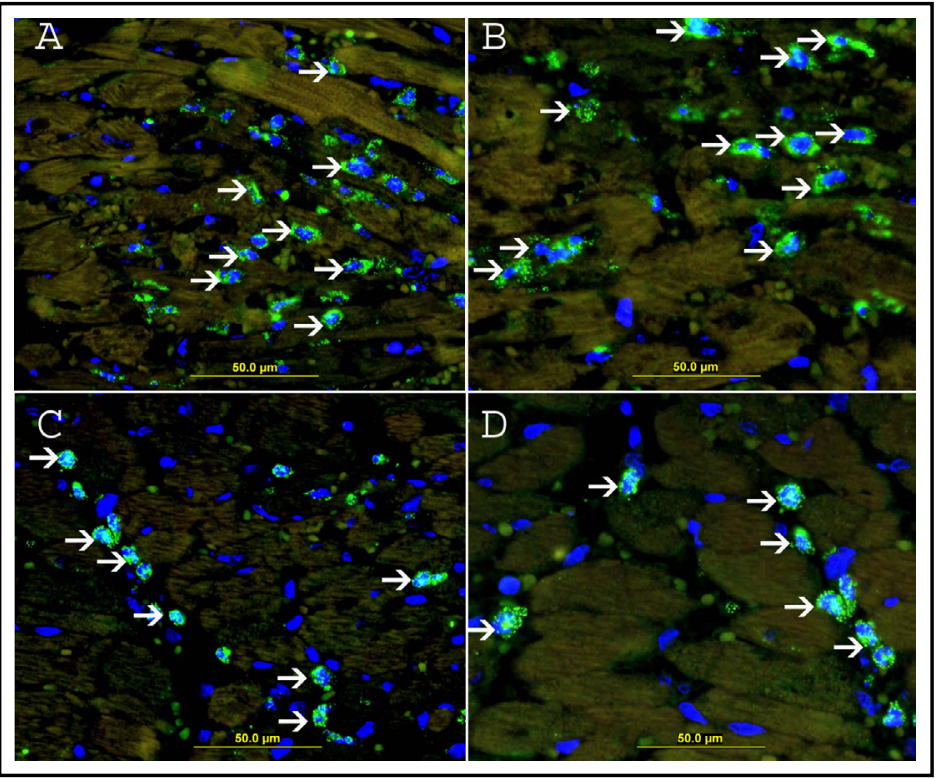

Fig. 4. The graphs represent (A) left ventricular total GSH concentrations in the wild type C57BL6 IR group and GAL-3 KO IR group. (B) Left ventricular catalase activity in the wild type C57BL6 IR group and GAL-3 KO IR group. Data are shown as means \pm SEM. Statistical significance is expressed $\mathrm{p}<0.05$.
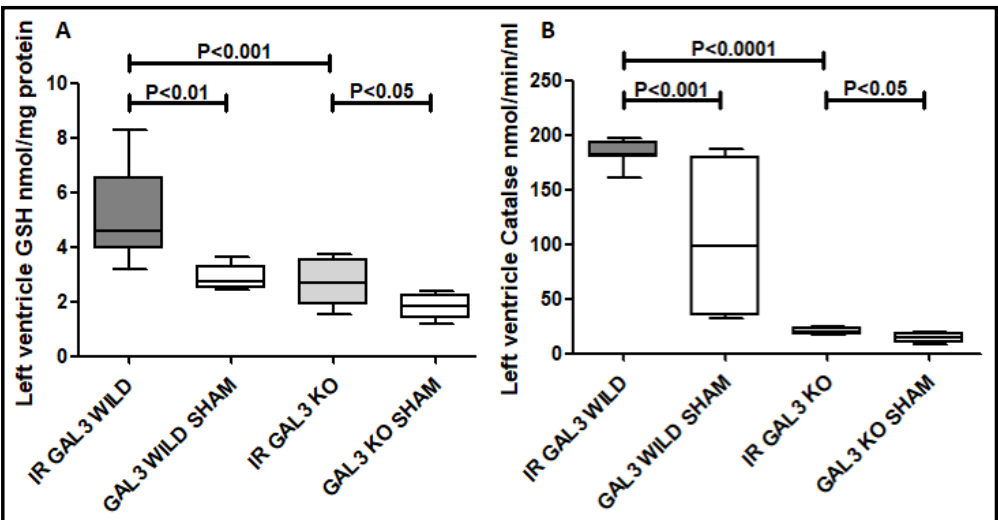


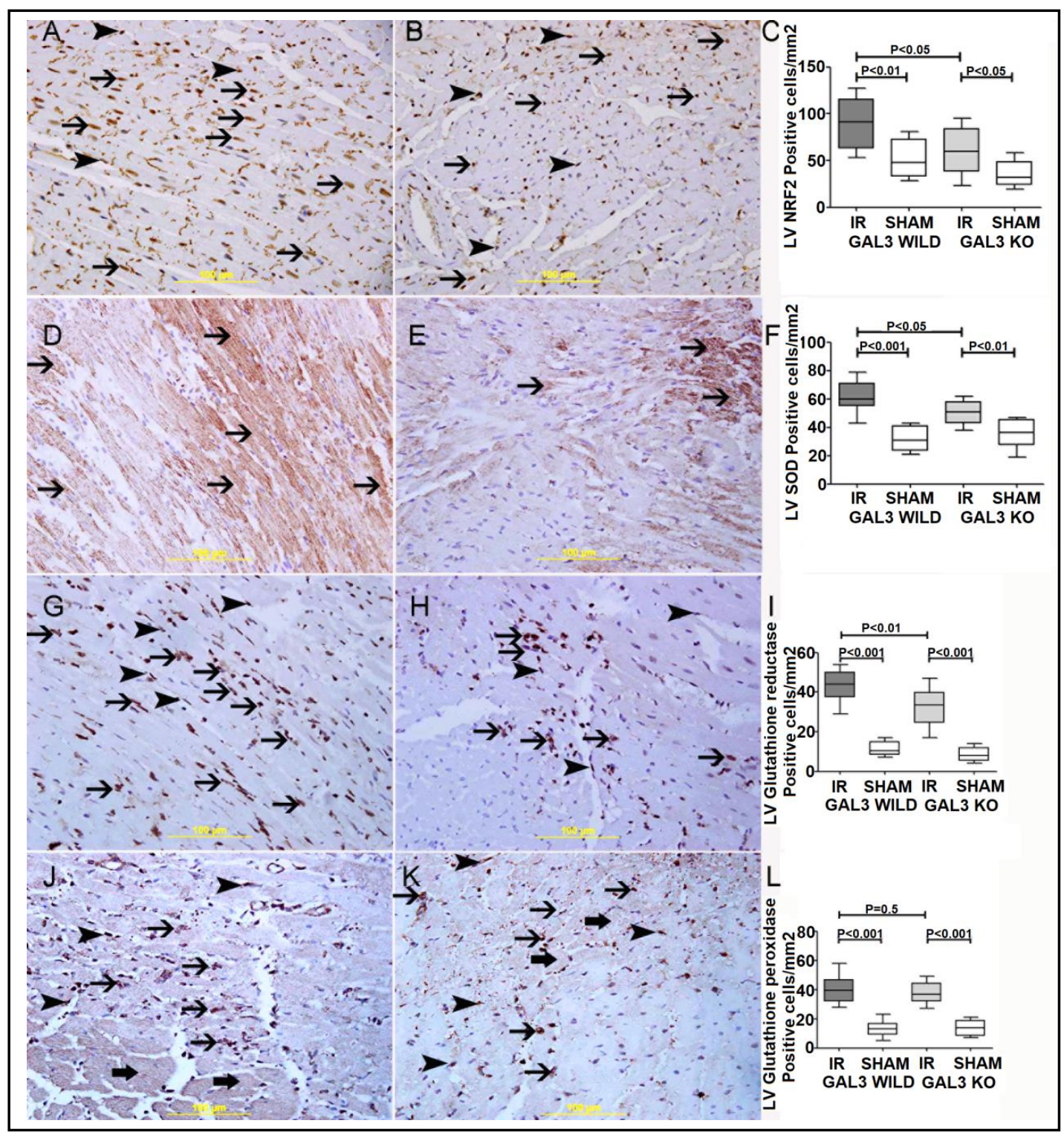

Fig. 5. Representative section of left ventricle (LV) showing nuclear expression of NRF2 by cardiac myocytes (thin arrow) and endothelial cells (arrow head) in IR GAL-3 wild mice (A) and IR GAL-3 KO mice (B). C. The graph represents morphometric analysis of NRF2 positive cells in GAL-3 wild IR \& GAL-3 KO IR groups as compared to their sham controls. Representative section of LV showing cytoplasmic expression of SOD by cardiac myocytes (thin arrow) in IR GAL-3 wild mice (D) and IR GAL-3 KO mice (E). F. The graph represents morphometric analysis of SOD positive cells in GAL-3 wild IR \& GAL-3 KO IR groups as compared to their sham controls. Representative section of LV showing cytoplasmic expression of glutathione reductase by neutrophil polymorphs (thin arrow) and endothelial cells (arrow head) in IR GAL-3 wild mice (G) and IR GAL-3 KO mice (H). I, The graph represents morphometric analysis of glutathione reductase positive cells in GAL-3 wild IR \& GAL-3 KO IR groups as compared to their sham controls. Representative section of LV showing cytoplasmic expression of glutathione peroxidase by neutrophil polymorphs (thin arrow), endothelial cells (arrow head) and cardiac myocytes (thick arrow) in IR GAL-3 wild mice (J) and IR GAL$3 \mathrm{KO}$ mice (K). L. The graph represents morphometric analysis of glutathione peroxidase positive cells in GAL-3 wild IR \& GAL-3 KO IR groups as compared to their sham controls. Data are shown as means \pm SEM. Statistical significance is expressed $\mathrm{P}<0.05$. 


\section{Cellular Physiology and Biochemistry}

Fig. 6. A\&B represent a low power view of heart sections showing a significantly increased expression of catalase (thin arrows) in the area supplied by the LAD in GAL-3 wild type IR group (A) as compared to the GAL-3 KO IR (B) group, Alexa Fluor 488 immunofluorescent labeling. C\&D represent high power view of heart section showing cardiomyocytes (thin arrows) and inflammatory cells (arrow heads) expressing catalase in GAL-3 wild type IR group (C). GAL-3KO IR group (D) shows comparatively fewer cardiomyocytes expressing catalase and mainly expressed by inflammatory cells (arrow heads), Alexa Fluor 488 immunofluorescent labeling. E, shows a high power view of GAL-3 wild type IR group showing catalase expression by cardiomyocytes (arrow heads), inflammatory cells (thin arrows). Some neutrophil polymorphs are surrounding a dead cardiomyocyte (thick arrow). F, represents a corresponding high power view of heart section from the GAL-3 KO IR group with visibly lower catalase expression in cardiomyocytes (thick arrow) and mainly expressed by inflammatory cells (arrow heads). Alexa Fluor 488 immunofluorescent labeling. G\&I show the low and high power view of the heart section of the GAL3 wild type IR group expressing catalase as a cytoplasmic staining of cardiomyocytes (arrow head) and endothelial cells (thick arrow). Streptavidin- biotin
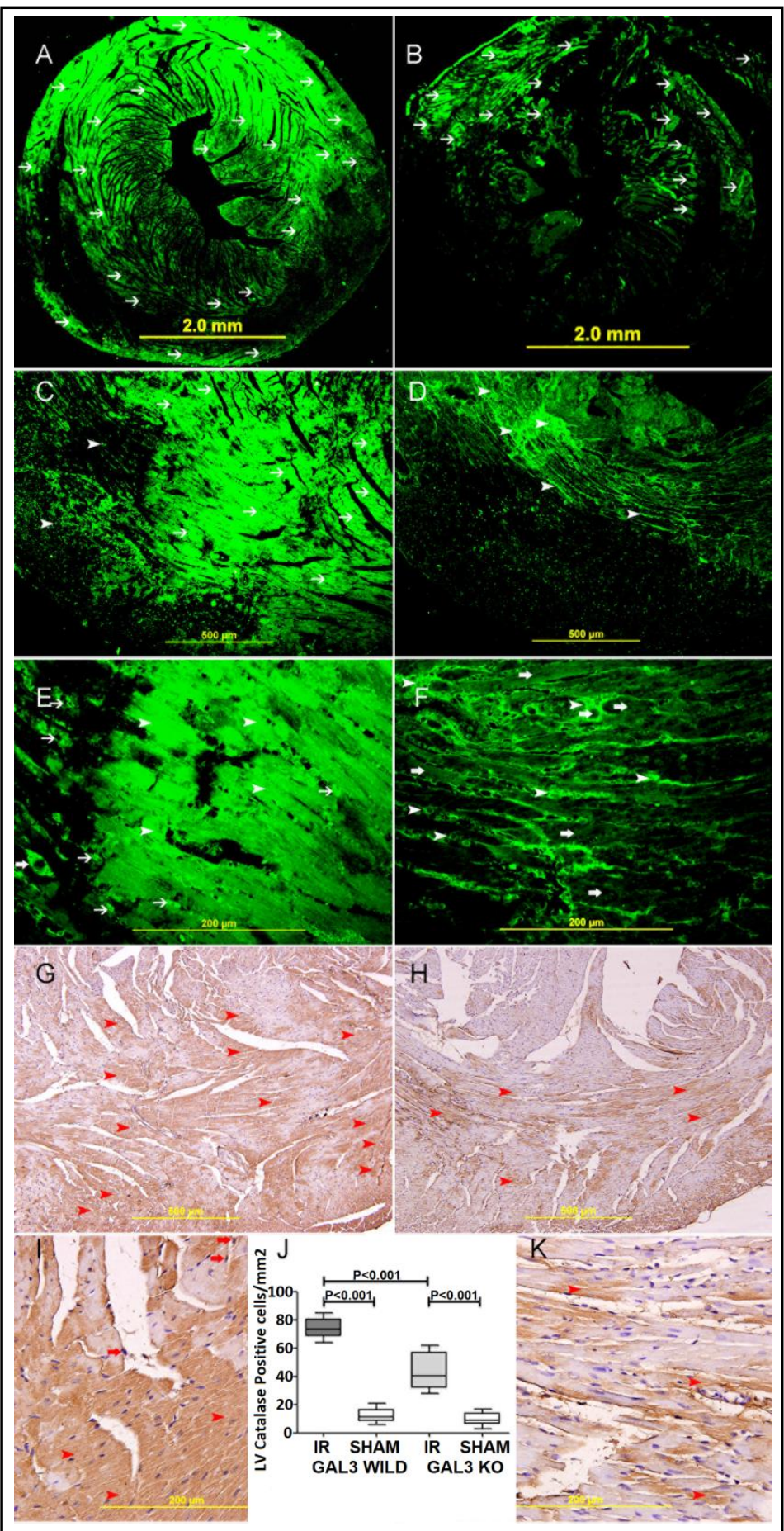

immunoperoxidase method. H\&K

represent low and high power views of the GAL-3 KO IR group showing a comparatively lower expression of catalase by cardiomyocytes (arrow head). Streptavidin- biotin immunoperoxidase method. J. The graph represents morphometric analysis of catalase positive cells in GAL-3 wild IR \& GAL-3 KO IR groups as compared to their Sham controls. Data are shown as means \pm SEM. Statistical significance is expressed $\mathrm{p}<0.05$. 
in GAL-3 wild IR group than in GAL-3 KO group, while there was no significant difference in the expression of glutathione peroxidase between GAL-3 wild IR group and GAL-3 KO group ( $40.38 \pm 3.433$ vs $37.63 \pm 2.605$, $p=0.5336$, Fig. 5J-L).

Morphometric analysis of immunohistochemically stained sections of LV show a higher number of cells showing cytoplasmic expression of catalase in GAL-3 wild IR group than in GAL-3 KO group (74.38 \pm 2.507 vs $43.50 \pm 4.516$, P<0.001, Fig. $6 \mathrm{~J})$.

\section{GAL-3 has an antiapoptotic effect in IR injury}

Heart LV cleaved caspase-3 levels were significantly increased in the IR KO group as compared to the IR group ( $2367 \pm 125.0 \mathrm{~N}=8$ vs $2027 \pm 93.47 \mathrm{pg} / \mathrm{mg}$ protein. $P<0.05)$ using ELISA technique.

The relative heart LV cleaved caspase-3, cytochrome $\mathrm{C}$, and BAX proteins expressions normalized to beta actin by western blot technique were significantly increased in IR KO group as compared to the IR group $(0.4758 \pm 0.01614$ vs $0.1938 \pm 0.01097 P<001),(0.6079$ \pm 0.02013 vs $0.3152 \pm 0.02035 P<001)$, and $(1.137 \pm 0.04690$ vs $0.8375 \pm 0.02711 P<001)$ respectively, (Fig. 7). While the relative heart LV BCL2 protein expression normalized to beta actin by western blot technique was significantly higher in IR group as compared to the IR KO group (2.523 \pm 0.04012 vs $1.067 \pm 0.04912 P<0.001)$, (Fig. 7).

Fig. 7. A, Western blot analysis of cleaved caspase-3, cytochrome C, BAX, BCL2 and beta actin proteins in GAL-3 wild IR \& GAL3 KO IR groups as compared to their sham controls. B, Graphical representation of densitometry analysis of cleaved caspase- 3 protein band normalized to beta actin band in GAL-3 wild IR \& GAL-3 KO IR groups as compared to their sham controls. C. Graphical representation of densitometry analysis of cytochrome $\mathrm{C}$ protein band normalized to beta actin band in GAL-3 wild IR \& GAL3 KO IR groups as compared to their sham controls. D. Graphical representation of densitometry analysis of BAX protein band

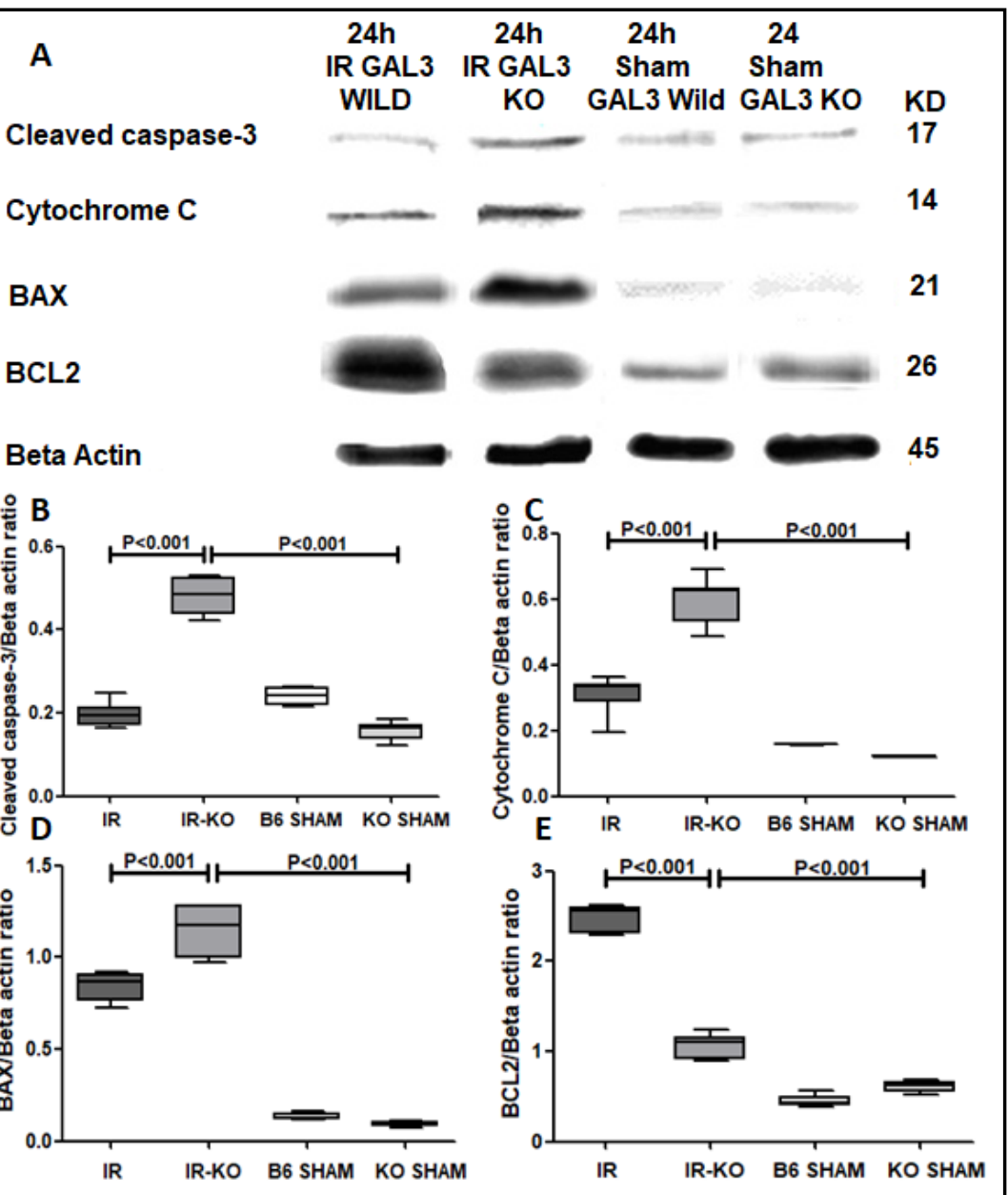
normalized to beta actin band in GAL-3 wild IR \& GAL-3 KO IR groups as compared to their sham controls. E. Graphical representation of densitometry analysis of BCL2 protein band normalized to beta actin band in GAL-3 wild IR \& GAL-3 KO IR groups as compared to their sham controls. Data are shown as means \pm SEM. Statistical significance is expressed $\mathrm{P}<0.05$. 


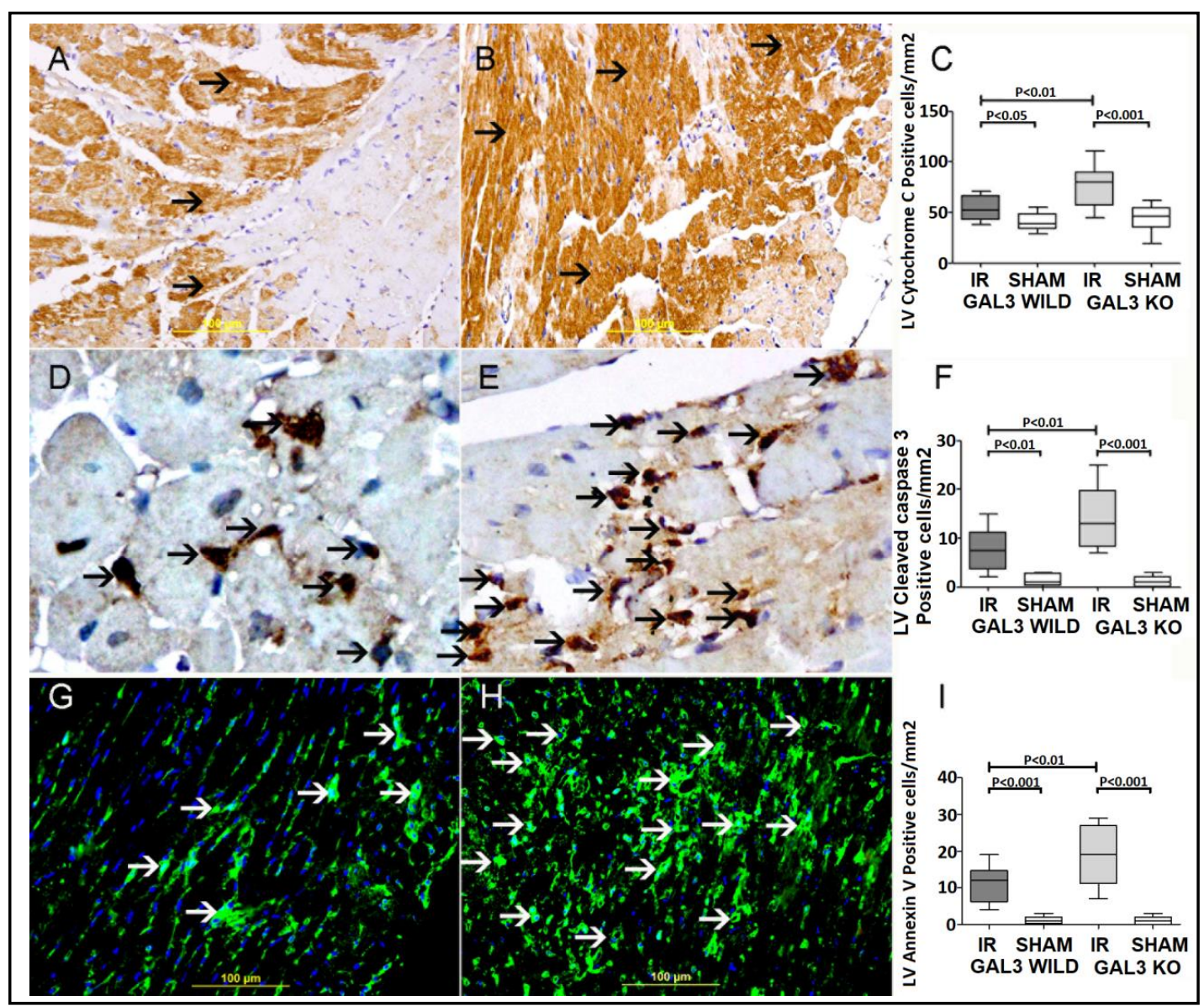

Fig. 8. Representative section from the left ventricle (LV) showing cytoplasmic expression of cytochrome $\mathrm{C}$ in cardiac myocytes (thin arrow) in IR group (A) and IR-KO group (B). C, The graph represents morphometric analysis of cytochrome $\mathrm{C}$ positive cells in GAL-3 wild IR \& GAL-3 KO IR groups as compared to their sham controls. Data are shown as means \pm SEM. Statistical significance is expressed $P<0.05$. Representative section from the LV of the showing apoptotic cell expressing cleaved caspase -3 (thin arrow) in IR group (D) and IR-KO group (E). F. The graph represents morphometric analysis of cleaved caspase-3 positive cells in GAL-3 wild IR \& GAL-3 KO IR groups as compared to their sham controls. Data are shown as means \pm SEM. Statistical significance is expressed $\mathrm{P}<0.05$. Representative section from the $\mathrm{LV}$ showing apoptotic cell expressing Annexin v on the cell membrane (thin arrow) in IR group (G) and IR-KO group (H) (Alexa Fluor 488). I, the graph represents morphometric analysis of annexin V positive cells in GAL-3 wild IR \& GAL-3 KO IR groups as compared to their sham controls. Data are shown as means \pm SEM. Statistical significance is expressed $\mathrm{P}<0.05$.

Morphometric analysis of immunohistochemically stained sections of the LV show a significantly higher number of cells showing cytoplasmic expression of cytochrome $\mathrm{C}$ in GAL-3 KO IR group than in GAL-3 IR wild group $(76.50 \pm 7.459$ vs $53.75 \pm 4.317, P<0.01$, Fig. 8A-C) Morphometric analysis of immunohistochemically stained sections of the LV show a significantly higher number of apoptotic cells stained with cleaved caspase-3 in GAL-3 KO IR group than in GAL-3 wild IR group (14.00 \pm 2.268 vs $7.625 \pm 1.558$ vs, $P<0.01$, Fig. 8D-F).

Morphometric analysis of immunohistochemically stained sections of the LV show a significantly higher number of apoptotic cells stained with annexin V in GAL-3 KO IR group than in GAL-3 wild IR group (18.63 \pm 2.897 vs $11.13 \pm 1.807, P<0.01$, Fig. $8 G-I)$ 
Total Troponin I in IR injury

Plasma Troponin I levels were significantly increased in the IR KO group as compared to the IR group (8.96931 $\pm 1.3845 \mathrm{vs} 3.727 \pm 1.168 \mathrm{pg} / \mathrm{mg}$ protein $P<0.001$ ) (Fig. 9).

\section{Discussion}

Myocardial infarction is the leading cause of death in cardiovascular diseases worldwide. The magnitude of myocardial injury relates directly to the degree of reduction of blood flow and to the duration of the ischemic insult, which affects the levels to which cellular ATP and intracellular $\mathrm{pH}$ are reduced. The impairment of ATPase-dependent ion transport during ischemic insult causes intracellular and mitochondrial calcium levels to increase. At the same time cell volume regulatory mechanisms are disturbed due to the lack of

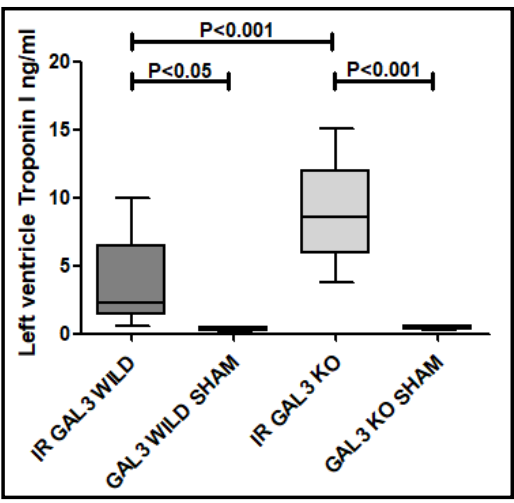

Fig. 9. The graphs represent plasma troponin I concentrations in the wild type C57BL6 IR group and GAL-3 KO IR group. Data are shown as means \pm SEM. Statistical significance is expressed $\mathrm{p}<0.05$. ATP, which can induce disintegration of micro organelles and plasma membranes $[8,34]$. Reperfusion, although required to rescue ischemic tissues, produces contradictory tissue responses that stimulate the production of reactive oxygen species, cause sequestration of proinflammatory cells in ischemic tissues, endoplasmic reticulum stress, and development of post ischemic capillary no-reflow, which amplifies tissue injury. These pathologic events terminate in opening of mitochondrial permeability transition pores as an end result of IR-induced cell death [1, 5, 35].

Blumgart et al. [36] reported that extensive infarction occurred when coronary occlusion was maintained for 40 minutes or longer, while occlusions of 5-20 minutes did not result in infarction. With occlusions of intermediate duration, the extent of necrosis depended on the time to reperfusion [37]. In our project we induced myocardial ischemia for 30 minutes followed by 24 hours reperfusion creating an environment where ischemic damage is limited to a time when irreversible damage starts to occur and 24 hour of reperfusion time gives adequate time for reperfusion related changes to take place.

Our aim in this study is to look at an acute time point after IR to see if GAL-3 plays any significant protective role at this early stage.

Our results show a significant increase in GAL-3 levels in the heart LV after IR injury as compared to sham-operated mice signifying that GAL-3 has some roles at this acute stage after IR. Troponin I, a marker of cardiomyocytes injury, is also significantly higher in GAL-3KO group than GAL-3 wild group. In addition, proapoptotic proteins such as cleaved caspase 3 , cytochrome $c$ and annexin V are significantly higher in GAL-3-KO group than GAL-3 wild group, while BCL2, an antiapoptotic protein, is significantly higher in GAL-3 wild group than GAL-3-KO group, supporting the notion that the raised GAL-3 post IR injury may in some way play a protective role (at least at the tested time point) in response to injury. Literature has many reports regarding anti-apoptotic role of GAL-3. GAL-3 has been shown to translocate either from the cytosol or from the nucleus to the mitochondria following exposure to apoptotic stimuli and blocks changes in the mitochondrial membrane potential, thereby preventing apoptosis [38]. GAL-3 has also been shown to translocate to the perinuclear membranes and inhibit cytochrome c release from the mitochondria and thereby inhibiting apoptosis [39]. GAL-3 can inhibit TNF- induced apoptosis through activation of AKT [40]. These anti-apoptotic effects of GAL-3 is further supported by the fact that overexpression of GAL-3 protects cell damage and death by motivating mitochondrial homeostasis [41].

The antioxidants glutathione and catalase levels are also significantly increased in the GAL-3 wild group as compared with the GAL-3 KO group. This shows that GAL-3 is associated with an increase in the antioxidant activity in the IR injured myocardium. The morphometric 


\section{Cellular Physiology Cell Physiol Biochem 2018;50:1123-1139 \\ \begin{tabular}{ll|l} 
DOl: 10.1159/000494539 & $\begin{array}{l}\text { O } 2018 \text { The Author(s). Published by S. Karger AG, Basel } \\
\text { www.karger.com/cpb }\end{array}$ \\
\cline { 2 - 4 }
\end{tabular} \\ Al-Salam et al.: Role of Galectin-3 in Myocardial Ischemia Reperfusion Injury}

analysis of immunohistochemically-stained sections also shows higher expression of NRF2, SOD, GSH reductase, and catalase in GAL-3 wild group than in GAL-3 KO group which also supports antioxidant role of GAL-3. This is another evidence supporting the protective role of GAL-3 at 24-hour following IR injury.

SOD, glutathione and catalase are the most important cellular defense mechanism against oxidative injury and are the major intracellular redox buffer in ubiquitous cell types $[42,43]$. Accumulating evidence suggests that the intracellular redox status regulates various aspects of cellular function [43]. Glutathione and catalase specifically provide significant antioxidant protection to the myocardium against IR injury [44-47]. Experiments using isolated heart models in the presence or absence of superoxide dismutase also showed ROS as likely mediators of reperfusion injury $[48,49]$.

Studies have shown that GAL-3 actions with regards to oxidative stress are variable; some point to its role as an inducer of ROS, but other studies explain its role as a molecule that is protective against ROS mediated injuries. In an ischemia reperfusion model in kidney it was shown that ROS production was more prominent in GAL-3 wild type mice as compared to GAL-3 knockout mice [50]. Early data have also demonstrated that GAL-3 could stimulate superoxide production by neutrophils [51] and by monocytes [52]. So the presence of GAL-3 produces more ROS and more antioxidant proteins.

In our study we found higher anti-oxidant activity in the LV myocardium after IR in conjunction with less myocardial damage in GAL-3 wild group than GAL-3 KO group. There can be many explanations for this phenomenon. The function of antioxidant systems is to modify the highly reactive oxygen species to form intermediates, which no longer pose a threat to the cell. A balance is essential between oxidation and antioxidant's level in the system for healthy biological integrity to be maintained. In previous studies, ischemia and reperfusion impaired superoxide dismutase activity and decreased cellular glutathione-toglutathione disulfide ratio suggested that the extent of superoxide anion radical produced at reperfusion exceeded the capacity of endogenous cellular antioxidant systems [53]. But the same oxidative stress can lead to increase in the antioxidant capacity and so the increase we see in the antioxidant enzymes may be due to the increase in the oxidative stress. This phenomenon was observed in a study by Bandeira et al. when the total SOD activity and the lipid peroxidation were higher in diabetics compared to non-diabetics [54]. Another study by Savu et al. also showed increase in anti-oxidant capacity despite high levels of oxidative stress [55]. Cabigas et al. have also shown over expression of catalase in myeloid cells following acute myocardial infarction [56].

Regarding the role of GAL-3 in IR, Matarrese et al. [41] have reported that GAL-3 interferes with ROS generation and so might interfere with very early stages of cell death that are associated with perturbation of mitochondrial homeostasis and subsequent formation of ROS. They also report that overexpression of GAL-3 protects cells from death through inhibition of ROS formation by promoting mitochondrial homeostasis. Mukaru et al. [57], have also shown increased GAL-3 is associated with increased GSH level. There is further evidence in literature that indicate that GAL-3 is protective in IR injuries e.g. GAL-3 was found to be involved in the kidney regeneration [58] and has also shown to play a protective role in ischemia reperfusion injury of the liver [59].

Thus the increase in the anti-oxidant activity linked to GAL-3, observed in the present study, may suggest two possibilities; either it is the result of a possible adaptive response, probably due to the increased production of the oxidative radicals or due to the inherent role of GAL-3 in decreasing oxidative stress.

An interesting observation in our study was that the immunohistochemical expression of NRF2 positive cells was higher in the GAL-3 wild type mice than in GAL-3 KO mice after IR injury.

This shows that GAL-3 caused an increase in the NRF2 expression in the myocardium. There have been no reports in literature, to date, showing a direct relationship between GAL3 and NRF2, however, NRF2 has been shown to control intracellular ROS levels following IR injury in cardiac cell culture [60]. Also in animal experiments, acute activation of NRF2 has 


\section{Cellular Physiology Cell Physiol Biochem 2018;50:1123-1139 \begin{tabular}{ll|l} 
DOI: 10.1159/000494539 & $\begin{array}{l}\text { O 2018 The Author(s). Published by S. Karger AG, Basel } \\
\text { www.karger.com/cpb }\end{array}$ \\
\hline
\end{tabular}}

been shown to be cardioprotective following IR injury [27, 61]. We can therefore hypothesize that GAL-3 confers protection partly through the NRF2 cytoprotective pathway.

IR injury is also associated with influx of inflammatory cells comprising predominantly of neutrophil polymorphs. CRP, IL-6, MPO, and neutrophil elastase are reliable markers for determining the magnitude of inflammatory response [62,63]. We show significantly higher levels of LV CRP, IL6, MPO, and neutrophil elastase in IR GAL-3 wild group as compared to the IR GAL-3 KO group. This observation supports a pro-inflammatory role of GAL-3 in IR injury. We have identified that knocking out GAL-3 gene results in a significant decrease in LV inflammatory markers as well as a significant increase in LV cell death. This paradox is very interesting and suggests multiple roles of GAL-3 in IR injury and that although knocking out GAL-3 is associated with lowering inflammatory response, it leads to an increase in cell death through increased apoptotic rate and decreased anti-oxidative activity. All these are pointing towards a protective role of GAL-3 at 24-hour post IR injury. Although GAL-3's role as a pro-inflammatory mediator is shown in our work and in previous studies [11, 64], we do not have a clear mechanistic understanding as to how this role reconciles with its protective role after IR injury.

\section{Conclusion}

Our study shows that GAL-3 can affect the redox pathways, controlling cell survival and death, and play a protective role on the myocardium following IR injury.

\section{Acknowledgements}

The authors would like to thank The Zayed Bin Sultan Center for Health Sciences and the United Arab Emirates University for their support of this project. In addition, we would like to thank Ms Manjusha Sudhadevi, Ms Hiba Taj Eldin Naser and Mr Karthishwaran Kandhan from department of pathology, College of Medicine \& Health Sciences, United Arab Emirates University, for their technical support.

\section{Disclosure Statement}

The authors declare to have no competing interests.

\section{References}

1 Piper HM, García-Dorado D, Ovize M: A fresh look at reperfusion injury. Cardiovasc Res 1998;38:291-300.

2 Keeley EC, Boura JA, Grines CL: Primary angioplasty versus intravenous thrombolytic therapy for acute myocardial infarction: a quantitative review of 23 randomised trials. Lancet 2003;361:13-20.

-3 Bulluck H, Yellon DM, Hausenloy DJ: Reducing myocardial infarct size: challenges and future opportunities. Heart 2016;102:341-348.

4 Hearse DJ, Humphrey SM, Chain EB: Abrupt reoxygenation of the anoxic potassium-arrested perfused rat heart: a study of myocardial enzyme release. J Mol Cell Cardiol 1973;5:395-407. Yellon DM, Hausenloy DJ: Myocardial reperfusion injury. N Engl J Med 2007;357:1121-1135. Frangogiannis NG, Dewald O, Xia Y, Ren G, Haudek S, Leucker T, Kraemer D, Taffet G, Rollins BJ, Entman ML: Critical role of monocyte chemoattractant protein-1/CC chemokine ligand 2 in the pathogenesis of ischemic cardiomyopathy. Circulation 2007;115:584-592.

7 Buja LM: Myocardial ischemia and reperfusion injury. Cardiovasc Pathol 2005;14:170-175.

8 Hausenloy DJ, Yellon DM: Myocardial ischemia-reperfusion injury: a neglected therapeutic target. J Clin Invest 2013;123:92-100. 


\section{Cellular Physiology Cell Physiol Biochem 2018;50:1123-1139 \begin{tabular}{l|l|l} 
DOI: 10.1159/000494539 & O 2018 The Author(s). Published by S. Karger AG, Basel \\
wwww.karger.com/cpb
\end{tabular}}

Al-Salam et al.: Role of Galectin-3 in Myocardial Ischemia Reperfusion Injury

-9 Barondes SH, Cooper DN, Gitt MA, Leffler H: Galectins. Structure and function of a large family of animal lectins. J Biol Chem 1994;269:20807-20810.

10 Hsu DK, Yang RY, Pan Z, Yu L, Salomon DR, Fung-Leung WP, Liu FT: Targeted disruption of the galectin-3 gene results in attenuated peritoneal inflammatory responses. Am J Pathol 2000;156:1073-1083.

11 Colnot C, Ripoche MA, Milon G, Montagutelli X, Crocker PR, Poirier F: Maintenance of granulocyte numbers during acute peritonitis is defective in galectin-3-null mutant mice. Immunology 1998;94:290-296.

12 Sano H, Hsu DK, Yu L, Apgar JR, Kuwabara I, Yamanaka T, Hirashima M, Liu FT: Human galectin-3 is a novel chemoattractant for monocytes and macrophages. J Immunol 2000;165:2156-2164.

13 Hughes RC: The galectin family of mammalian carbohydrate-binding molecules. Biochem Soc Trans 1997;25:1194-1198.

14 Hughes RC: Secretion of the galectin family of mammalian carbohydrate-binding proteins. Biochim Biophys Acta 1999;1473:172-185.

15 Hashmi S, Al-Salam S: Galectin-3 is expressed in the myocardium very early post-myocardial infarction. Cardiovasc Pathol 2015;24:213-223.

16 Pesheva P, Kuklinski S, Biersack HJ, Probstmeier R: Nerve growth factor-mediated expression of galectin-3 in mouse dorsal root ganglion neurons. Neurosci Lett 2000;293:37-40.

17 Morrow DA, O’Donoghue ML: Galectin-3 in cardiovascular disease: a possible window into early myocardial fibrosis. J Am Coll Cardiol 2012;60:1257-1258.

18 Zweier JL: Measurement of superoxide-derived free radicals in the reperfused heart. Evidence for a free radical mechanism of reperfusion injury. J Biol Chem 1988;263:1353-1357.

19 Raedschelders K, Ansley DM, Chen DD: The cellular and molecular origin of reactive oxygen species generation during myocardial ischemia and reperfusion. Pharmacol Ther 2012;133:230-255.

20 Weiss SJ: Oxygen, ischemia and inflammation. Acta Physiol Scand Suppl 1986;548:9-37.

-21 Kensler TW, Wakabayashi N, Biswal S: Cell survival responses to environmental stresses via the Keap1Nrf2-ARE pathway. Annu Rev Pharmacol Toxicol 2007;47:89-116.

22 Lee JM, Johnson JA: An important role of Nrf2-ARE pathway in the cellular defense mechanism. J Biochem Mol Biol 2004;37:139-143.

23 Itoh K, Wakabayashi N, Katoh Y, Ishii T, Igarashi K, Engel JD, Yamamoto M: Keap1 represses nuclear activation of antioxidant responsive elements by Nrf2 through binding to the amino-terminal Neh2 domain. Genes Dev 1999;13:76-86.

-24 Kobayashi A, Kang MI, Okawa H, Ohtsuji M, Zenke Y, Chiba T, Igarashi K, Yamamoto M: Oxidative stress sensor Keap1 functions as an adaptor for Cul3-based E3 ligase to regulate proteasomal degradation of Nrf2. Mol Cell Biol 2004;24:7130-7139.

25 Gorrini C, Harris IS, Mak TW: Modulation of oxidative stress as an anticancer strategy. Nat Rev Drug Discov 2013;12:931-947.

26 Muthusamy VR, Kannan S, Sadhaasivam K, Gounder SS, Davidson CJ, Boeheme C, Hoidal JR, Wang L, Rajasekaran NS: Acute exercise stress activates Nrf2/ARE signaling and promotes antioxidant mechanisms in the myocardium. Free Radic Biol Med 2012;52:366-376.

27 Zhang Y, Sano M, Shinmura K, Tamaki K, Katsumata Y, Matsuhashi T, Morizane S, Ito H, Hishiki T, Endo J, Zhou H, Yuasa S, Kaneda R, Suematsu M, Fukuda K: 4-hydroxy-2-nonenal protects against cardiac ischemiareperfusion injury via the Nrf2-dependent pathway. J Mol Cell Cardiol 2010;49:576-586.

28 Chen XL, Dodd G, Thomas S, Zhang X, Wasserman MA, Rovin BH, Kunsch C: Activation of Nrf2/ARE pathway protects endothelial cells from oxidant injury and inhibits inflammatory gene expression. Am J Physiol Heart Circ Physiol 2006;290:H1862-1870.

29 Braun S, Hanselmann C, Gassmann MG, auf dem Keller U, Born-Berclaz C, Chan K, Kan YW, Werner S: Nrf2 transcription factor, a novel target of keratinocyte growth factor action which regulates gene expression and inflammation in the healing skin wound. Mol Cell Biol 2002;22:5492-5505.

30 Cho HY, Reddy SP, Yamamoto M, Kleeberger SR: The transcription factor NRF2 protects against pulmonary fibrosis. FASEB J 2004;18:1258-1260.

31 Michael LH, Entman ML, Hartley CJ, Youker KA, Zhu J, Hall SR, Hawkins HK, Berens K, Ballantyne CM: Myocardial ischemia and reperfusion: a murine model. Am J Physiol 1995;269:H2147-2154.

-32 Michael LH, Ballantyne CM, Zachariah JP, Gould KE, Pocius JS, Taffet GE, Hartley CJ, Pham TT, Daniel SL, Funk E, Entman ML: Myocardial infarction and remodeling in mice: effect of reperfusion. Am J Physiol 1999;277:H660-668. 


\section{Cellular Physiology Cell Physiol Biochem 2018;50:1123-1139 and Biochemistry \begin{tabular}{l|l} 
DOI: 10.1159/000494539 & $\begin{array}{l}\text { O } 2018 \text { The Author(s). Published by S. Karger AG, Basel } \\
\text { wwww.karger.com/cpb }\end{array}$
\end{tabular} and Biochemistry}

Al-Salam et al.: Role of Galectin-3 in Myocardial Ischemia Reperfusion Injury

33 Hashmi S, Al-Salam S: Loss of dystrophin staining in cardiomyocytes: a novel method for detection early myocardial infarction. Int J Clin Exp Pathol 2013;6:249-257.

-34 Avkiran M, Marber MS: $\mathrm{Na}(+) / \mathrm{H}(+)$ exchange inhibitors for cardioprotective therapy: progress, problems and prospects. J Am Coll Cardiol 2002;39:747-753.

-35 Braunwald E, Kloner RA: Myocardial reperfusion: a double-edged sword? J Clin Invest 1985;76:1713-1719.

-36 Blumgart HL, Gilligan MS, Schlesinger MJ: Experimental studies on the effect of temporary occlusion of coronary arteries: II. The production of myocardial infarction. Am Heart J 1941; 22: 374-389.

-37 Braunwald E: Personal reflections on efforts to reduce ischemic myocardial damage. Cardiovasc Res 2002;56:332-338.

-38 Matarrese P, Fusco O, Tinari N, Natoli C, Liu FT, Semeraro ML, Malorni W, Iacobelli S: Galectin-3 overexpression protects from apoptosis by improving cell adhesion properties. Int J Cancer 2000;85:545554.

-39 Yu F, Finley RL Jr, Raz A, Kim HR: Galectin-3 translocates to the perinuclear membranes and inhibits cytochrome c release from the mitochondria. A role for synexin in galectin-3 translocation. J Biol Chem 2002;277:15819-15827.

40 Oka N, Nakahara S, Takenaka Y, Fukumori T, Hogan V, Kanayama HO, Yanagawa T, Raz A: Galectin-3 inhibits tumor necrosis factor-related apoptosis-inducing ligand-induced apoptosis by activating Akt in human bladder carcinoma cells. Cancer Res 2005;65:7546-7553.

-41 Matarrese P, Tinari N, Semeraro ML, Natoli C, Iacobelli S, Malorni W: Galectin-3 overexpression protects from cell damage and death by influencing mitochondrial homeostasis. FEBS Lett 2000;473:311-315.

-42 Jolly SR, Kane WJ, Bailie MB, Abrams GD, Lucchesi BR: Canine myocardial reperfusion injury. Its reduction by the combined administration of superoxide dismutase and catalase. Circ Res 1984;54:277-285.

-43 Nakamura H, Nakamura K, Yodoi J: Redox regulation of cellular activation. Annu Rev Immunol 1997;15:351-369.

-44 Ceconi C, Curello S, Cargnoni A, Ferrari R, Albertini A, Visioli O: The role of glutathione status in the protection against ischaemic and reperfusion damage: effects of $\mathrm{N}$-acetyl cysteine. J Mol Cell Cardiol 1988;20:5-13.

45 Singh A, Lee KJ, Lee CY, Goldfarb RD, Tsan MF: Relation between myocardial glutathione content and extent of ischemia-reperfusion injury. Circulation 1989;80:1795-1804.

46 Chen Z, Siu B, Ho YS, Vincent R, Chua CC, Hamdy RC, Chua BH: Overexpression of MnSOD protects against myocardial ischemia/reperfusion injury in transgenic mice. J Mol Cell Cardiol 1998;30:2281-2289.

47 Woo YJ, Zhang JC, Vijayasarathy C, Zwacka RM, Englehardt JF, Gardner TJ, Sweeney HL: Recombinant adenovirus-mediated cardiac gene transfer of superoxide dismutase and catalase attenuates postischemic contractile dysfunction. Circulation 1998;98:II255-260; discussion II260-251.

48 Shlafer M, Kane PF, Wiggins VY, Kirsh MM: Possible role for cytotoxic oxygen metabolites in the pathogenesis of cardiac ischemic injury. Circulation 1982;66:I85-92.

\$9 Ambrosio G, Becker LC, Hutchins GM, Weisman HF, Weisfeldt ML: Reduction in experimental infarct size by recombinant human superoxide dismutase: insights into the pathophysiology of reperfusion injury. Circulation 1986;74:1424-1433.

-50 Fernandes Bertocchi AP, Campanhole G, Wang PH, Gonçalves GM, Damião MJ, Cenedeze MA, Beraldo FC, de Paula Antunes Teixeira V, Dos Reis MA, Mazzali M, Pacheco-Silva A, Câmara NO: A Role for galectin-3 in renal tissue damage triggered by ischemia and reperfusion injury. Transpl Int 2008;21:999-1007.

51 Yamaoka A, Kuwabara I, Frigeri LG, Liu FT: A human lectin, galectin-3 (epsilon bp/Mac-2), stimulates superoxide production by neutrophils. J Immunol 1995;154:3479-3487.

52 Liu FT, Hsu DK, Zuberi RI, Kuwabara I, Chi EY, Henderson WR: Expression and function of galectin-3, a betagalactoside-binding lectin, in human monocytes and macrophages. Am J Pathol 1995;147:1016-1028.

53 Guarnieri C, Flamigni F, Caldarera CM: Role of oxygen in the cellular damage induced by re-oxygenation of hypoxic heart. J Mol Cell Cardiol 1980;12:797-808.

54 Bandeira SeM, Guedes GaS, da Fonseca LJ, Pires AS, Gelain DP, Moreira JC, Rabelo LA, Vasconcelos SM, Goulart MO: Characterization of blood oxidative stress in type 2 diabetes mellitus patients: increase in lipid peroxidation and SOD activity. Oxid Med Cell Longev 2012;2012:819310.

-55 Savu O, Ionescu-Tirgoviste C, Atanasiu V, Gaman L, Papacocea R, Stoian I: Increase in total antioxidant capacity of plasma despite high levels of oxidative stress in uncomplicated type 2 diabetes mellitus. J Int Med Res 2012;40:709-716. 


\section{Cellular Physiology Cell Physiol Biochem 2018;50:1123-1139 \begin{tabular}{ll|l} 
and Biochemistry & $\begin{array}{l}\text { DOl: 10.1159/000494539 } \\
\text { Published online: } 24 \text { October } 2018\end{array}$ & $\begin{array}{l}\text { O } 2018 \text { The Author(s). Published by S. Karger AG, Basel } \\
\text { www.karger.com/cpb }\end{array}$ \\
\cline { 2 - 3 }
\end{tabular} \\ Al-Salam et al.: Role of Galectin-3 in Myocardial Ischemia Reperfusion Injury}

56 Cabigas EB, Somasuntharam I, Brown ME, Che PL, Pendergrass KD, Chiang B, Taylor WR, Davis ME: Overexpression of catalase in myeloid cells confers acute protection following myocardial infarction. Int J Mol Sci 2014;15:9036-9050.

57 Mukaro VR, Bylund J, Hodge G, Holmes M, Jersmann H, Reynolds PN, Hodge S: Lectins offer new perspectives in the development of macrophage-targeted therapies for COPD/emphysema. PLoS One 2013;8:e56147.

58 Vansthertem D, Cludts S, Nonclercq D, Gossiaux A, Saussez S, Legrand A, Gabius HJ, Toubeau G: Immunohistochemical localization of galectins- 1 and -3 and monitoring of tissue galectin-binding sites during tubular regeneration after renal ischemia reperfusion in the rat. Histol Histopathol 2010;25:14171429.

59 Lee YJ, Song YK: Cooperative interaction between interleukin 10 and galectin-3 against liver ischemiareperfusion injury. Clin Cancer Res 2002;8:217-220.

60 Cao Z, Zhu H, Zhang L, Zhao X, Zweier JL, Li Y: Antioxidants and phase 2 enzymes in cardiomyocytes: Chemical inducibility and chemoprotection against oxidant and simulated ischemia-reperfusion injury. Exp Biol Med (Maywood) 2006;231:1353-1364.

61 Calvert JW, Jha S, Gundewar S, Elrod JW, Ramachandran A, Pattillo CB, Kevil CG, Lefer DJ: Hydrogen sulfide mediates cardioprotection through Nrf2 signaling. Circ Res 2009;105:365-374.

62 Faith M, Sukumaran A, Pulimood AB, Jacob M: How reliable an indicator of inflammation is myeloperoxidase activity? Clin Chim Acta 2008;396:23-25.

63 Willerson JT, Ridker PM: Inflammation as a cardiovascular risk factor. Circulation 2004;109:II2-10.

64 Kuwabara I, Liu FT: Galectin-3 promotes adhesion of human neutrophils to laminin. J Immunol 1996;156:3939-3944. 